\title{
STRATEGIES TO BE IMPLEMENTED ABOUT FLEET PLANNING IN AIRLINES AND THE EXAMINATION OF TRIPLE FLEET PLANNING MODEL
}

DOI: $10.17261 /$ Pressacademia.2019.1082

PAP-V.9-2019(29)-p.144-149

Tuzun Tolga Inan ${ }^{1}$

${ }^{1}$ istanbul Gelişim University, Faculty of Economics and Social Sciences, İstanbul, Turkey. ttolgainan83@gmail.com , ORCID: 0000-0002-5937-9217

To cite this document

Inan, T., T., (2019). Strategies to be implemented about fleet planning in airlines and the examination of triple fleet planning model. PressAcademia Procedia (PAP), V.9, p.144-149

Permemant link to this document: http://doi.org/10.17261/Pressacademia.2019.1082

Copyright: Published by PressAcademia and limited licenced re-use rights only

\section{ABSTRACT}

Purpose- The main aim of this study is to determine civil aviation sector which mostly affected by current changes in the world and has entered a great upward trend since the beginning of the 1990s with globalized and marked at the last twenty five years as a growth rate. In this twenty five years old growth, airlines have competed each other with a wide range of strategies. In this competitive environment, fleet planning is one of the forefront issues which affect airlines. Another major expense item fuel prices are not changed except by special agreements and the most optimal use of aircrafts about participated aircrafts appropriate with the missions and visions of airlines.

Methodology- In order to achieve this aim, the literature review of the important developments in the civil aviation sector in the last twentyfive years has been carried out and all these literature surveys have been examined and presented to the reader.

Conclusion- As a result of the analyzes, it has been revealed that the civil aviation sector has diversified greatly in terms of both technological and customer satisfaction in the last twenty-five years. The most important element of this differentiation is the low-cost transport strategy that started to be implemented in the early 90 s and started to become more widespread in the early 2000 s.

Keywords: Maintenance planning document, analitic network process, novel approach to imprecise assessment and decision environments, swaps, three stage airline fleet planning model.

JEL Codes: Y50, Y80, Y90, Z00.

\section{HAVAYOLLARINDA FILO PLANLAMASI DOĞRULTUSUNDA UYGULANAN STRATEJILER VE ÜÇLÜ FILO PLANLAMA MODELININ INCELENMESI}

\section{ÖZET}

Amaç- Bu çalışmanın temel amacı, 1990'lı yılların başından itibaren büyük bir yükseliş trendine giren ve globalleşen Dünyada mevcut değişimlerden en fazla etkilenen sektörlerden olan Sivil Havacılık büyüme oranı olarak son yirmi beş yıla damgasını vurmuştur. Bu yirmi beş yılık büyümede havayolları farklı stratejilerle birbirleri ile büyük bir rekabet içerisine girmişlerdir. Bu rekabet ortamında havayollarını en çok etkileyen konuların başında filo planlaması gelmektedir. Bir diğer büyük gider kalemi olan yakıt fiyatlarının özel anlaşmalar dışında değişiklik göstermediğini varsaydığımız zaman, havayollarının misyon ve vizyonlarına uygun uçakların bünyeye katılması ve bu doğrultuda bünyeye katılan uçakların en optimal şekilde kullanılmasıdır.

Yöntem- Bu amaca ulaşmak için, sivil havacılık sektöründe son yirmi beş yıldaki önemli gelişmelerin literatür taraması yapılmış olup, tüm bu literatür taraması aşama aşama incelenerek okuyucuya sunulmuştur.

Sonuç- Yapılan analizler sonucunda, sivil havacılık sektörünün son yirmi beş yılda hem teknolojik, hem de müşteri memnuniyetine yönelik büyük oranda farklılaştığı ortaya çıkmıştır. Bu farklılaşmanın en önemli unsurunu se 90'lı yılların başında uygulamaya geçen ve 2000'li yılların başında gitgide yaygınlaşmaya başlayan düşük maliyetli taşımacılık stratejisinin bu büyüme ve farklılaşmayı büyük oranda etkilemesidir.

Anahtar Kelimeler: Bakım planlama dokümanı, analitik ağ süreci, değerlendirme ve karar ortamlarını kestirmek için yeni yaklaşım, eşit takas yöntemi, üç aşamalı havayolu filo planlama modeli.

JEL Kodları: Y50, 7Y80, Y90, Z00.

\section{Gíriş}

Operasyonlara başlayan bir havayolu için uçak filosu seçiminin planlanması çok önemlidir. Uçak imalatçıları genellikle müşterilerini aşağıdaki dört kategoride temsil etmektedir. Bu kategoriler; uçak özellikleri, sistem konfigürasyon ekipmanları, kabin konfigürasyonu ve uçak eğlence konfigürasyonu olarak sınıflandırılmaktadır. İlk kategori olarak uçak özellikleri; uçağın boyutlarını, performansını, ağırlıklarını ve iç mekânını 
içerir. Kabin konfigürasyonu; filodaki uçakların tek, iki ve/veya üç ayrı koltuk sınıfına sahip olup olmadığını içerir. Sistem konfigürasyonu; müşterinin ihtiyaçlarına bağlı olarak kullanılan motor tipi, emisyon ve yakıt tasarrufu unsurlarını içerir. Uçak içi eğlence sistemi; seçilebilir ürünler olarak kabul edilir. Uçak filosu seçimi; öngörülen yolcu yük faktörleri, havayolu ulaşımını kullanan yolcuların talepleri ve rekabet ortamı gibi çeşitli faktörlere bağlı olmaktadır. Havayolları diğer taraftan kendi yapılarına sahiptir. Havayolu operasyonunu ve yapısını anlamak bir diğer deyişle havayolu dünyasının daha iyi anlaşılması; uçak tasarımları, uçakların satın alınması, satılması ve/veya kiralaması vb. gibi konular ile ilgilidir. Bir havayoluna verilen belirli bir uçağın uygunluğunu araştırmak için havayoluyla ilgili önemli bilgiler verilmelidir. Bu bilgiler; hangarların hacim olarak kapasiteleri, sayısı ve yapılan bakımlardır. Bu bakımlar dış kaynak ile sağlanıyorsa; bu kaynakların hangi hizmetler için dış kaynak olarak kullanıldığı, çalışan sayısı ve verilen maaşlar gibi konuları içermektedir. Örneğin filoya katılan bir uçak büyük bir havayolu için uygun olabiliyorken, küçük bir havayolu için uygun olmayabilir. Uçaktaki herhangi bir bakım, onarım, muayene ve/veya malzeme idaresi için imalatçı tarafından verilen Bakım Planlama Dokümanı (MPD - Maintenance Planning Document) bu konularla ilgilenmektedir. MPD uçakların çalışma süresince ne zaman hangi işlemin gerçekleştirilmesi gerektiği konusunda genel bakım ve hat bakımına ilişkin yönergeler sunar. Bakım işlemi ile ilgili olarak uçakların bakımı ikiye ayrılır. Temel bakım; genelde hangarda yapılması gereken rutin tüm önemli kontrolleri içerir, hat bakım ise; uçaklar için her uçuştan ve/veya günden güne yapılan kısa süreli bakım faaliyetleridir. Yerde kalma süresi veya başka bir deyişle uçağı operasyona hazırlamak için gereken süre, havayolları için önemli bir konudur. Uçak, havayolu, havalimanı ve hava trafik kontrol kulesinin açıkça etkileşimde bulunduğu her yer, uçağın yerde kaldığı sürenin doğru planlanması ile ilgilidir. Yerde kalma süresi ne kadar düşük olursa uçakların optimal kullanımı o kadar yüksek olur ve bu doğrultuda optimal kullanım doğrudan işletme maliyetlerini de düşürmektedir. Havalimanları açısından bakarsak uçakların daha kısa süre yerde kalması, havalimanındaki tıkanıklığını azalttığı gibi daha fazla yolcu havalimanından uçaklara daha kısa sürede geçiş yapabilir. Başarılı bir operasyon yapabilmek için, uçak filosunun yerde kalma süresinin planlanma aşaması iyi analiz edilmelidir. Bu nedenle havayolu filo planlama modeli oluşturulurken uçakların yerde kalma süreleri önem arz etmektedir. Uçak kapasiteleri, uçak tasarımı, uçakların menzili, uçakların yolcu kapasitesi, uçakların koltuk sınıfları, güzergah planlamaları, yakıt tasarrufu ve emisyon gibi kavramların uçakların filosundaki daha az uçak tipinde kullanıldığında, hem yerde kalma süresi daha iyi planlandığı gibi hem de bakım maliyetleri azaltılabilmektedir (Harasani, 2006, p. 6).

\section{LITERATÜR INCELEMESI}

\section{1. Üç Aşamalı Havayolu Planlama Modeli}

Pai pazardaki demografik bilgileri, havalimanı, havayolu ve güzergâh özelliklerini göz önüne alarak, Amerika Kıtasındaki hava trafiği bağlantıları için havayolu uçuş frekanslarını ve uçak boyutunu etkileyen faktörleri değerlendirmiştir (Pai, 2010, p. 169-177). Givoni ve Reitveld regresyon analizini kullanarak havalimanı özelliklerinin (pist sayısı, merkez veya merkez olmayan) uçak seçimini etkilemediği halde, mesafe, mevcut talep ve rekabetin seviyesi doğrultusunda planlanan güzergâh seçimlerinin uçak boyutlarının belirlenmesinde önemli ölçüde etkili olduğunu savunmuştur (Givoni ve Reitveld, 2009, p. 163). Wei ve Hansen uçakların boyutu, frekansları, koltuk doluluk durumu ve uçak bileti talebinin iki büyük havayolunun hâkim olduğu rekabet ortamındaki hava trafiğinin, havayolu pazar payına olan etkisini araştırmak için iç içe geçmiş bir logit modeli geliştirmiştir. Geliştirilen logit modele göre uçak başına koltuk doluluk oranını arttırmak yerine, havayolunun frekanslarını artırarak daha fazla pazar payı elde ettiğnii belirtilmiştir (Wei ve Hansen, 2005, p. 315-327). Givoni ve Rietveld, başka bir çalışmada küçük menzilli uçakların kısa mesafeli güzergâhlar üzerindeki etkilerini karşılaştırmışlardır. Bu karşılaştırma yapılırken sektörde yer alan havayollarının konumlarını korumaları için uçuş frekansının önemini ve havayollarının özellikle kısa mesafelerde daha büyük koltuk konfigürasyonuna bağlı uçakları kullandıklarını belirtmişlerdir (Givoni ve Rietveld, 2010, p. 504). Oum ve arkadaşları, havayollarının bilançolarının içeriğinde uçak kiralamanın çok etkin olduğu üzerinde odaklanmışlardır. Kısa sürede ilave kapasiteye ihtiyaç duyan bir havayolu kendi çabaları doğrultusunda uçak üretici firmalarla avantajlı anlaşmalara ulaşamayabilirken, büyük uçak kiralama şirketleri ile çalışan bir havayolu kapasite ve talebini ayarlayarak uzun vadeli uçak alım ve kiralamalarında çok daha avantajlı anlaşmalardan faydalanabilmektedir (Oum vd., 2000, p. 21). Özdemir ve arkadaşları, Türk Hava Yolları için orta menzilli ve tek koridorlu uçakları seçmek amacıyla ANP (Analitik Ağ Süreci - Analitic Network Process) yöntemini kullanmışlardır. Bu yöntemde maliyet esasları (satın alma, çalıştırma, yedek parça, bakım ve kurtarma maliyeti), zaman kavramı (teslim süresi ve amortisman) ve fiziksel nitelikler göz önüne alınmıştır. Bu faktörlerin dışında; boyutlar, güvenlik, güvenilirlik ve hizmet kalitesi için uygunluk kavramları da alt ölçütler olarak belirlenmiştir (Özdemir vd., 2011, p. 1156). Gomes ve arkadaşları Brezilya'daki bölgesel tarifesiz uçuşlardaki uçak seçimi sorununu araştırmışlardır. Araştırmanın sonucunda NAIADE (Değerlendirme ve Karar Ortamlarını Kestirmek İçin Yeni Yaklaşım - Novel Approach to Imprecise Assessment and Decision Environments) isimli çok kriterli karar verme yöntemine bağlı olarak üç kriter grubu (finans, lojistik ve kalite sistemlerinin incelenmesi) stratejisini kullanmışlardır (Gomes vd., 2014, p. 226).

\section{Şekil 1: Üç Aşamalı Havayolu Planlama Modeli}

Bharda uçak seçimi ve hava ulaşımı talebi arasındaki ilişkiyi belirlemek amacıyla bir soruyu cevaplamaya çalışmaktadır. Bu soru; güzergâh olarak belirlenen noktalar için yolcu talebini temel alarak, bulunduğumuz ve gidilecek nokta arasındaki ulaşım için uçak ve filo seçimini farkı stratejilerle uygulamak mümkün müdür? Şeklinde tanımlanmıştır (Bharda, 2003). Listes ve Dekker, yolcular için seyahat talebi değişikliklerini dikkate alarak filo yapısını belirlemek için örneklendirme tabanlı bir yaklaşım geliştirerek, filo yapısını stratejik açıdan incelemişlerdir (Listes ve Dekker, 2005, p. 373). Kilipi'ye göre standartlaştırılmış ve çeşitlendirilmiş filo arasındaki seçim havayolları için zorlu bir süreçtir. Çeşitlendirilmiş uçak tiplerinden oluşan bir filo piyasa koşullarına cevap verecek birçok uçağı seçme imkânı sunarken, standartlaştııılmış bir filo daha az bakım, eğitim ve işçilik maliyetleri anlamına gelmektedir. Standartlaştııılmış filoda maliyetlerin daha düşük olmasına rağmen, olumsuz yanı güzergâh seçimleri itibariyle havayolunun gelişme potansiyelinin az olmasıdır. Çeşitlendirilmiş filoda da maliyetler daha yüksek olup, havayolunun gelişme potansiyeli güzergâh seçimi itibariyle daha fazla olabilmektedir (Kilipi, 2007, p. 85). Sivil Havacilık sektörü 
uluslararası mecrada son on yılda ekonomik kriz, terörist saldırılar vb. nedeniyle çok çalkantılı bir dönem geçirmektedir. İstikrarsız ekonomik ortamdan kaynaklanan belirsiz talep, tahmin ve planlamayı zorlaştırmaktadır. Bu nedenle havayolları için en önemli konulardan filo planlama problemi daha karmaşık ve önemli hale gelmektedir. Dolayısıyla da bu durum yazarları filo planlama problemini araştırmaya teşvik etmektedir. Bu çalışmada, havayolları için uçak filolarının en iyi şekilde değerlendirilebilmesi ile ilgili kararlarında yardımcı olacak üç aşamalı bir havayolu filo planlama modeli analiz edilmiştir. Bu araştırmanın ilgili literatüre ana katkısı ise daha önceki çalışmalar tek filo veya karmaşık filo seçimi konularında ayrı ayrı değerlendirme eğiliminde olduğundan, belirtilen modelin planlamacılara bu iki karar ile ilgili olarak nispeten daha iyi analiz edilmiş bir stratejinin kazandırımış olabilme ihtimalidir. Ayrıca ilgili model oluşturulurken farklı havayollarında çalışan planlama uzmanlarının değerli iç bilgi ve deneyimlerinden ilgili modelin oluşumu doğrultusunda faydalanılmıştır. Bu modelin çoğunlukla kısa ve orta menzilli güzergâhlarda uçuşlarını gerçekleştiren havayollarının filo planlamasında kullanılması amaçlanmıştır. Uzun mesafeli güzergâhların bu modelde dikkate alınmamasının sebebi, uzun mesafe uçuşların genellikle ülkelerin bayrak taşıyıcı havayolları tarafından yapılması ve alternatif olarak değerlendirmeye alınmasının zor olmasıdır.

\subsection{Havayollarında Filo Planlaması}

Filo planlaması havayolları için çok önemli bir kavramdır. Filo planlaması ile havayolları amaçlarını gerçekleştirmek için hangi tür uçakların hangi sayıda satın alması gerektiğini belirtmektedir. Filo planlamacılar uçak ve motor üreticileri ile müzakere anlaşmalarında yer almakla birlikte karar verme sürecinin büyük kısmı filo planlaması için planlanmaktadır. Filo planlamasının temel unsurlarını anlamak, havayollarının ihtiyaçlarını ve çalışma parametrelerini anlamaktır. Filo planlamasına bağlı olmayan ikili ve/veya çoklu anlaşmalar, insan faktörleri ve havayolu çalışanları gibi yeni uçak alımlarını etkileyen diğer faktörlerin de bulunduğunu belirtmek gerekir. Örneğin, Airbus uçakları arasında farklı özelliklerin bulunduğunu ve Airbus'tan farklı boyutlarda bir filoya sahip olmanın avantajının bulunduğunu iddia ederek uçak üretim pazarına giriş yapmıştır. Bu özellikleri sıralarsak: Sistemsel unsurlardan dolayı pilotların Airbus'ta uçabilmek için aynı tipteki diğer uçaklara nazaran eğitim için daha az zamana ihtiyacı vardır. Airbus uçakları aynı tipteki diğer uçaklara nazaran eğitim, bakım ve işgücü faktörleri süreçlerini daha kısa sürede çözümler. Airbus uçaklarında kullanılan sistemsel özellikler temel alındığında; yakıt ikmali, bagaj taşıma, bakım, uçakları çalıştırmak için kullanılan araçlar ve bu esaslar altında hazırlanan prosedürler uygun şekilde kullanıldı̆̆ından, ilgili faktörlerin işletme maliyetlerinin azaltılması hususunda büyük etkisi olmaktadır. Örneğin aynı tip uçakların tüm filoda kullanılması, yeni uçak alımları için üreticilerle müzakerelerde iyi bir konumda olmamak anlamına gelebilmektedir ancak havayolunun karma bir filosu varsa, üreticilerle müzakereler konusunda fiyat avantajına daha rahat sahip olunabilmektedir. Filo planlamasının içerisinde; uçak değerlendirmesi, uçak karşılaştırması, güzergâh analizi, uçakların kullanım kolaylıkları ve talep ile arzın eşzamanlı değerlendirilmesi faktörlerinin teker teker değil hep birlikte en uygun koşullarla değerlendirebilmesi, havayolunun finansal ve faaliyet performansını olumlu yönde etkileyebilmektedir (Clark, 2001). Filo planlama kararının ve havayolunun filosundaki uçakların değerlendirilmesinin daha iyi anlaşılması, uçuş güzergâhı seçimlerinin oluşturulmasına yardımcı olmaktadır. Bir havayolunun en zor kararlarından biri, yeni veya kullanılmış bir uçak satın almak ya da mevcut uçakların ne zaman yenilenip yenilenmeyeceğinin kararının verilmesidir. Havayolları için filo planlamasının çıkmazlarını sıralarsak: Filoların karmaşık olması, kararların uzun vadeli olması, mevcut pazarın geçici olması ve uçuş ağlarının farklı yapıda yapılanmasıdır (Snow, 2004). Dolayısıyla filo planlaması mevcut koşullarda bir uzlaşma olup, doğru çözüm bulunmadığı zaman ise zarar etmek kaçınılmazdır. Her havayolunun mevcut teknolojik ortamda eldeki uçakların değiştirilmesi yönünde farklı yaklaşımları bulunmaktadır. Hükümet tarafından desteklenen havayollarının ve/veya mevcut sermayenin zengin olduğu havayolları daha genç uçak filosuna sahip olduklarından, uçak filosunun belirlenmesi kararı doğrultusunda zarar etme ihtimalleri daha az olmaktadır. Filo planlaması ayrıca havayolları için uçakların zamanında elden çıkarılması ve/veya zamanında bünyeye katılmasının değerlendirilmesi açısından yaşam döngüsü, sürekli devam eden bir süreçtir (Taylor, 2005).

\section{YÖNTEM}

\section{1. Üçlü Filo Planlama Modeli}

Şekil 1 üç aşamalı filo planlama modelinin planını göstermektedir. Bu modelde, birinci aşamadaki belirli güzergâhlar doğrultusunda uçak boyutları açısından tahmini bir filo karması kararlaştırır. Karara istinaden her güzergâha mevcut seçenekler içerisindeki talebe ve mesafeye göre küçük veya orta boyutlarda uçak ataması yapılır. Birinci aşamada belirtilen güzergâh planlamasına göre, ikinci aşamada gerekli uçak sayısı belirlenir. Üçüncü aşamada ise en iyi şekilde talebi karşılayacak olan uçak tipi seçimleri belirlenmektedir.

\subsubsection{Birinci Aşama - Tahmini Filo Karışımı}

Havayolu planlamasının (uçuş planlaması, güzergâh planlaması ve filo planlaması) doğası gereği belirsiz olan hava seyrüsefer talep tahminlerine dayandığı bilinmektedir. Bulanık mantık sistemi, tahminlerde ve belirsizlikle başa çıkmayı planlarken sıklıkla kullanılır. Bulanık mantık sistemleri, karmaşık planlama sürecini modellemek için sayısal ve bu doğrultuda ortaya çıkan metin bilgilerini birleştirebilme yetisine sahiptir (Teodorovic, 1999, s. 345). Bu çalışmada belirsiz talep ve filo karışımı kavramları, metin olarak (küçük, orta ve büyük talep veya küçük ve orta uçak) açıklanmıştır ve havayolu planlamacılarının bilgi ve tecrübelerine dayalı olarak bulanık mantık sistemi uygulanmıştır. Bulanık mantık sisteminin evrensel bir yaklaşıma (regresyon analizine benzer) sahiptir. Yaklaşık filo karışımını belirlemek için, uçakları iki kategoriye, küçük ve orta boy uçaklar (kısa menzilli ve orta mesafeli güzergâhlar) olarak sınıflandırmamız gerekir. Küçük bir uçak ortalama 50-100 koltuk kapasitesine sahipken, orta boy bir uçak 101-200 koltuk kapasitesine sahiptir. Belirtilen her kategori farklı uçak tiplerinden oluşmuştur. Bharda havayolunun çoğunlukla kullandığı merkez havalimanının (hub) yolcu talebinin, mesafesinin ve türlerinin, iyi uçak tipi seçimini tahmin etmek için uygun olduğunu bulmuştur. Bu nedenle yolcu talepleri ve kalkış ve varış havalimanları arasındaki mesafe, filo karışımını (küçük veya orta boy uçakların kullanılıp kullanılmayacağının kararı) belirlemek için kullanılır (Bharda, 2003). Geçmiş yıllardaki belirli bir güzergâh üzerinde kullanılan uçaklar mevcut yolcu talebini ve pazarın genel durumunu yansıtmaktadır. Piyasa ve talep değişiklikleri bu doğrultuda uçak boyutunun belirlenebilmesini sağlamaktadır. Bu nedenle geçmiş filo atama verileri, gelecekte kullanılacak olan uçakların boyutunu tahmin etmek için kullanılabilir. Bu veriler, geçmişteki resmi havalimanı tarifelerinden elde edilerek (mevsimler için ayrı ayrı analiz edilerek) gelecek yıllar için hesaplanabilmektedir. Belli bir güzergâh için uçak seçerken, bir havayolu genellikle belli uçak tipleri için tercih seçeneğine sahiptir. 
Bu tercihin ileriki yıllardaki gelire etkisi "daha güçlü" veya "daha zayıf" olabilir. Filo planlama modelimizin ilk aşamasında öncelikle dikkate alınan güzergâhlar için tablo ikide yer alan üçlü sistem anlayışı sunulmuştur.

\section{Şekil 2: Üç Aşamalı Havayolu Planlama Model}

\section{Bulanık mantık sistemi kullanımına göre uçak seçimi} kararında mutlak bir tercih bulunmamaktadır.

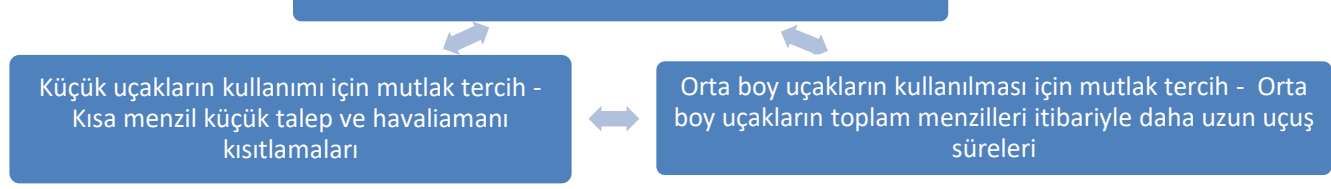

Şekil ikide yer alan üçlü sistem anlayışı doğrultusunda uçuş süresine bağlı olarak uçak tipi ve güzergâh seçimleri, havayollarının filo planlaması doğrultusunda daha iyi analiz edilerek belirlenebilmektedir. Şekil ikiden yararlanılarak uçuş güzergahı seçimleri şekil üçteki dokuzlu sistem anlayışına göre belirlenebilmektedir.

Kural 1 Eğer talep düşük ve mesafe kısa ise tercih çok düşük aksi takdirde,

Kural 2 Eğer talep düşük ve mesafe orta ise tercih düşük aksi takdirde,

Kural 3 Eğer talep düşük ve mesafe yüksek ise tercih orta aksi takdirde,

Kural 4 Eğer talep orta ve mesafe kısa ise tercih düşük aksi takdirde,

Kural 5 Eğer talep orta ve mesafe orta ise tercih orta aksi takdirde,

Kural 6 Eğer talep orta ve mesafe yüksek ise tercih yüksek aksi takdirde,

Kural 7 Eğer talep yüksek ve mesafe kısa ise tercih orta aksi takdirde,

Kural 8 Eğer talep yüksek ve mesafe orta ise tercih yüksek aksi takdirde,

Kural 9 Eğer talep yüksek ve mesafe uzun ise tercih çok yüksek olması durumu olmak üzere küçük ve orta gövde uçakların güzergah seçimleri dokuz kuralın analizi doğrultusunda şekillenebilir.

Verilen yıllık talep ve kalkış ve varış havalimanları arasındaki mesafe için filo planlamasında küçük ve orta gövde uçakların işletilmesine yönelik tercih kararı, Kalic, Kuljanin ve Dozic'e göre dokuzlu uçuş güzergahı seçimi sistem anlayışını kullanılarak belirlenebilir (Kalic, vd., 2013, p. 281).

\subsection{2. Íkinci Aşama - Filo Boyutlandırma}

Modelin ikinci aşaması bir havayolunun belirli bir uçuş programını kullanması gereken az sayıda uçağının uygun güzergahlarda kullanılması amacıyla birinci modelde elde edilen çıktıların, modelin ikinci aşamasında yer alan filo boyutlandırma aşamasına girdi olarak entegre edilmesi ile analiz edilir. Filo boyutlandırma aşamasını uygulamak için güzergâhları birinci aşamada belirlenen uçak tipi ana kategorisi, yolcu talep karakteristiklerine ve toplam gidilen mesafeye bağlı olarak alt gruplara ayrılmıştır. Başka bir deyişle her alt grup bir uçak tipini temsil eder, ancak aynı uçak tipi birden fazla alt grupta kullanılabilir. Yolcu talebi özellikleri, varış yerinin turistik mi yoksa iş amaçlı olup olmadığının bilgilerini içermektedir. Turistik güzergâhlarda taşınan bagaj miktarının, iş amaçlı güzergâhlara giden bagaj miktarından (iş gezginlerinin hâkim olduğu yerlerde) çok daha fazla olduğu belirtilmektedir. Bu nedenle bu güzergâhlarda kullanılan uçak tiplerinin bagaj yüklemesi için daha fazla alana sahip olması gerekmekte olup, filo planlamasının da seferlerin turistik veya iş amaçlı yapılma sıklığı doğrultusunda düzenlenmesi gerekmektedir. Filo boyutlandırma aşaması kendi merkez havalimanından veya önceki havalimanından gelerek uçuşunu tamamlayan ve yeni uçuşların günlük bazda tüm varış meydanındaki havalimanlarının müsaitlik durumuna göre düzenlenmesini içerir. Küçük ve orta boyuttaki uçak sayılarının filo boyutlandırma aşaması içerisinde belirlenmesi, aşağıdaki altı adım ayrı ayrı kullanılarak yapılabilir:

Birinci Aşama: Haftanın ilk gününün en erken saatindeki uçuş saatinden başlayarak, haftanın son günündeki en geç saatteki uçuşa kadar olan tüm sürecin en iyi şekilde planlanması.

İkinci Aşama: Yapılan planlama doğrultusunda haftanın ilk günündeki ilk uçağa sefer atamasının yapılması.

Üçüncü Aşama: Illk gündeki ikinci uçuşu örneklem olarak "mevcut uçak" havuzundan seçtikten sonra, uçağın önceki uçuşunun varış süresini tarifeli kalkış saati ile karşılaştırarak bir sonraki seferin bu kıstaslar altında devam ettirilmesi. Eğer herhangi bir gecikme olmadıysa bir sonraki havalimanına ulaşım konusunda üçüncü sefer aynı doğrultuda devam ettirilebilecektir. Eğer ikinci seferde bir gecikme yaşandıysa veya aksi bir durum olduysa mevcut filodan başka bir uçağın ilgili güzergâha ataması yapılacaktır.

Dördüncü Aşama: İlgili güzergâhla ilgili olarak devam eden seferler için birden fazla uçuş planlaması yapılabiliniyorsa, en erken zamanda hazır olacak uçak seçilir. Bu durumda da aynı tip uçaktan oluşturulan filolar havayoluna personel kullanımı, eğitim ve bakım kavramları değerlendirildiği zaman büyük gelir sağlayacaktır. Çünkü bu durumda tüm filoda aynı tip uçaklar kullanıldığı için, ataması yapılacak uçak hazır olmadığı zaman bile rastgele seçilecek başka bir uçak da ilgili güzergâh için atanabilecektir.

Beşinci Aşama: Filoda atanması gereken herhangi bir uçak yoksa gün içinde dönüş seferini gerçekleştiren herhangi bir uçak olup olmadığının kontrol edilmesi gerekir. Yapılan kontrol sonrasında cevap hayır ise süreç sonlandırılır. Gerekli uçak sayısı, filoda yer alan uçak sayısı ile eşdeğer olmalıdır. Eğer güzergâh sayısı artıyorsa da yeni getirilen uçak sayılarının, yeni güzergâh planlamaları için gereken uçak sayısı ile aynı 
şekilde eşdeğer olması gerekmektedir. Aksi takdirde filomuzda yeni bir uçağa ihtiyaç varsa, üçüncü adımda yer alan sürece göre hareket edilir. Eğer gün içinde dönüş yapan uçak yeni sefer için atanamıyorsa da bu sefer altıncı adımdaki sürecin uygulanması gerekmektedir.

Altıncı Aşama: Uçuş tarifesini planlarken her bir uçağın en az gittiği sayıda dönüş yapacak şekilde planlanması gerekmektedir. Bu planlamayı yaparken tüm gün boyunca filodaki her uçağın (teknik arıza, onarım vs. aksi bir durum yoksa) aynı şekilde maksimum verim alınacak şekilde değerlendirilmesi gerekir. Ancak filomuzdan maksimum şekilde verim alamıyorsak, geliş, kalkış ve varış havalimanları baz alınarak günlük uçuş seferlerindeki tarifeli saatler değiştirilemeyeceğinden iki ayrı planlamanın yapılması gerekir. Bu planlamalardan ilki daha önce bahsedilen mevcut filodaki aynı tipteki başka bir uçağın ilgili güzergâh için seçilmesidir (swaps yapmak). Diğer planlama ise filodaki uçakların sefer aralarında bir sonraki sefere hazırlanması için gereken yerde kalma sürelerinin (turnaround time) emniyet unsurundan ödün vermeyecek şekilde kısaltarak ve sonraki uçuşları da tarifeli saatlere en yakın şekilde hazırlayarak maksimum verim planlaması uygulamaya çalışılabilecektir (Dozic ve Kalic, 2015, s. 30-39).

\subsection{3. Üçüncü Aşama - Uçak Tipi Seçimi}

Uçak tipi seçimi çok kriterli bir karar sürecini içermektedir. Üçüncü aşamada uçak tipi seçimi probleminin çözümlenebilmesi için takas yönteminin uygulanması ana tema olmaktadır. Bu doğrultuda belirlenen eşit takas (swaps) yöntemi ile çeşitli uçak tipi alternatifleri arasında en doğru planlama yapılarak uçak değişimi doğrultusunda başka uçakların ilgili sefere atanması konusunda pratik çözüm bulunabilmektedir. Eşit takas yönteminde tüm alternatifler belirli bir amaç için eşit olarak derecelendirilir ve dikkate alınan alternatifler arasından bu doğrultuda seçim yapılır. Eşit takas yönteminde ilk adım, tüm hedefleri sol tarafa ve olası alternatifleri üst kısımlara listeleyerek bir sonuç tablosu oluşturmaktır. Bir diğer deyişle sütunlar sonuçlarla açıklanan alternatifleri sunmakta olup, satırlar da her alternatif için sonuç vermektedir. Sonuçlar tablosu doğru şekilde tanımlandığında, bir karar verici bir veya daha fazla alternatifi ortadan kaldırma fırsatı bulabilecektir. İşlemi kolaylaştırmak için bir sıralama tablosu oluşturulması önerilir. Sıralama tablosunda, her bir alternatif sonuçlar tablosunda sıralanır ve prosedür her bir alternatif için sırayla tekrarlanır. Sıralama tablosu, tüm hedeflere göre alternatiflerin karşılaştırıımasını ve baskın alternatifleri tanımlamayı mümkün kılar. Bir alternatif bazı hedeflerle daha kötüyse ve diğer tüm hedeflerle de daha iyi değilse, değerlendirmeye alınmaz. Mevcut alternatifleri bu doğrultuda ortadan kaldırdıktan sonra, alternatiflerin sayısını azaltmak için pratik karar verme yöntemi ortaya konmalıdır. Pratik karar verme yöntemi, bir alternatifin bazı hedeflerle daha kötü ya da eşit olması ve yalnızca tek bir hedefle daha iyi olması anlamına gelmektedir. Pratik karar verme yöntemine göre uygun olan alternatifler, başka bir alternatifinin eşit takas yöntemine göre daha iyi olduğuna karar verilirse seçilen alternatif de ortadan kaldırılabilir. Kısacası filodaki en iyi alternatif uçak seçilene kadar eşit takas ve pratik alternatif yöntemleri ile en iyi seçenek aranmaya devam edilir. Bir hedef her seçenekte aynı şekilde sıralandığında, karar verilmesi için ilgili hedefin yanlış olduğu düşünülmektedir. Hatta eşit takas yöntemi ile farklı hedefler, değerlerini tüm alternatifler arasında eşit hale getirmek ve nihai olarak bu kıyaslamaları daha ayrıntılı ve objektif yapabilmek için eşit ayarlama fırsatı sağlar. Bu nedenle de bu yönteme eşit takas denilmiş olup, bir hedefin gelişen teknoloji, değerini zamanla kaybettiren amortisman vs. sebeplerinden dolayı değerinin düştüğü zaman yeni diğer hedeflerin bu doğrultuda eşdeğer değerini artırdığı anlamına gelmektedir. Bir hedefin diğer hedeflere göre daha uygun olduğu için seçilebilmesi amacıyla hedeflerin birbiriyle karşılaştırılarak sadece bir hedef kalana kadar hedef sayısı azaltılabilinmektedir. Bu aşamada çözülmesi gereken problem, uygun sefere uygun tipteki uçağın atanması işlemidir. Bazen uçakların daha iyi performans göstermesi veya talebi daha iyi bir şekilde eşleştirmek için filoda bulunan uçakların sefer yaptığı güzergâh seçeneklerini alt gruplara ayırmak gerekir. Bu durum da kıyaslama yapabilmek amacıyla bir havayolunun bir uçak tipinden fazla sayıda uçak tipini filosunda bulundurmasını gerektirir. Ancak bu şekilde havayolunun planlamasında yer alan güzergâhlara uygun uçak ataması kararı verilebilir. Uçak tipi seçimi çok kriterli bir karar verme sürecidir. Örneğin, bir havayolu makul fiyat ve ödeme koşullarında uçak veya uçaklar satın almak istiyorsa, bu uçak veya uçakların uygun kapasite ve teknik performansa sahip olması gerekir. Filoya uygun uçak tipi seçimi yaparken beş faktör dikkate alınmaktadır: 1) Uçak koltuğu kapasitesi, 2) yeni uçakların fiyatı 3) yolcu başına bagaj sayısı, 4) maksimum kalkış ağırığı (MTOW - Maximum Take Off Weight) ve 5) sefer başına (cycle) yapılan yakıt, bakım, uçuş ekibi, sigorta, amortisman ve diğer bazı giderler şeklinde sıralanmaktadır. Koltuk kapasitesi, arz ve talebi karşılamak için bir araç niteliğindedir. Yeni uçakların fiyatı (milyonlarca ABD doları) oldukça yüksek miktarlarda olduğundan, satın alma işleminde sınırlayıcı bir faktör olmaktadır. Bu nedenle ayrıca hesaplanması ve dikkate alınması gerekir. Yolcu başına bagaj (metreküp (m3) olarak) belirli bir rotadaki yolcuların niteliğine bağlı olarak hesaplanır. Daha önce de belirtildiği üzere turistik güzergâhlarda daha fazla bagajın taşımacılığı yapıldığı için, bu güzergâhlarda bagajlar için daha fazla kargo hacmine sahip uçaklara ihtiyaç duyulmaktadır. Havalimanına verilen ücretler ve ayrıca taşımacılık için harcanan diğer ücretler ile birlikte, uçağın maksimum kalkış ağırlığı düşünülmesi gereken kritik konumdaki bir etkendir. Belirli uçak tipleri tarafından gerçekleştirilen belirlenmiş uçuşlar için birim maliyetlerin (mevcut koltuk kilometre başına gider) havayollarının gelir-gider dengesi dikkate alınacak şekilde planlanması gerekmektedir (Hammond vd., 1998, p. 140; Hammond ve Keeney, 1999a, 1999b, p. 73).

\section{SONUÇ VE ÖNERILER}

Bu çalışmada havayollarında uçak filosu seçimi yapılırken dikkate alınması gereken konular incelenmiştir. İlk olarak konu ile ilgili farklı görüşler sunulmuştur. İkinci olarak havayollarında filo planlamasının nasıl yapıldığına dair örnekler ele alınmıştır. Son olarak filo planlama modeli başlığı altında üç aşamalı analiz yöntemi incelenmiştir. Tahmini filo karışımı, filo boyutlandırma ve uçak tipi seçimi sırasıyla incelenen filo planlama modeli ile uçak filo seçimi ile ilgili literatüre katkı sağlanmaya çalışılmış olunup, özellikle kısa ve orta gövdeli uçakların seçilme nitelikleri doğrultusunda inceleme yapılmıştır. Kısa ve orta gövdeli uçakların incelenmesinin sebebi, geniş gövde uçakların çoğunlukla ülkelerin bayrak taşıyıcı havayolları tarafından kullanılması ve uçak tipi seçimi kavramı doğrultusunda kıyaslama ve değerlendirme amaçlı fazla seçeneğe sahip olunamamasıdır. 


\section{KAYNAKÇA}

Bharda, D. (2003). Choice of Aircraft Fleets in the US NAS: Findings from a Multinomial Logit Analysis. https://www.mitre.org/sites/default/files/pdf/bhadra_analysis.pdf. Erişim Tarihi 01.01.2018

Clark, P. (2001). "Buying the Big Jets, Fleet Planning for Airlines", Aldershot: Asqate.

Dozic, S., Kalic, M. (2015). Three-stage airline fleet planning model. Journal of Air Transportation Management, 46, p. 30-39.

Givoni, M., Reitveld, P. (2009). Choice of aircraft size e explanations and implications. J. Air Transp. Manag., 16, p. $159-167$.

Givoni, M., Reitveld, P. (2010). The environmental implications of airlines' choice of aircraft size. Transp. Res. A Policy Pract., 43, p. 500-510.

Gomes, L.F.A.M., Fernandes, J.E.M., Soares de Mello, J.C.C.B., 2014. A fuzzy stochastic approach to the multicriteria selection of an aircraft for regional chartering. J. Adv. Transp., 48, p. 223-237.

Hammond, J.S., Keeney, R.L., Raifa, H. (1998). Even swaps: a rational method for making trade-offs. Harv. Bus. Rev., 76, p. 137-150.

Hammond, J.S., Keeney, R.L. (1999a). Smart Choices: a Practical Guide to Making Better Decisions. Harvard Business School Press, Boston.

Hammond, J.S., Keeney, R.L. (1999b). Making smart choices in engineering. IEEE Spectr., 36, p. 71-76.

Harasani, W.I. (2006). Evaluation and Selection of a Fleet of Aircraft for a Local Airline Aeronautical Engineering Department, Faculty of Engineering, King Abdulaziz University, Jeddah, Saudi Arabia JKAU: Eng. Sci., 17(2), p. 3-16.

Kalic, M., Kuljanin, J., Dozic, S. (2013). Air travel demand fuzzy modelling: trip generation and trip distribution. In: Snasel, V., Kromer, P., Koppen, M., Schaefer, G. (Eds.), Soft Computing in Industrial Applications. Springer, New York, p. 279-290. http://dx.doi.org/10.1007/978-3319-00930-8. Erişim Tarihi 02.01.2018

Kilipi, J. (2007). Fleet composition of commercial jet aircraft 1952-2005: developments in uniformity and scale. J. Air Transp. Manag., 13, p. 81-89.

Listes, O., Dekker, R. (2005). A scenario aggregation-based approach for determining a robust airline fleet composition for dynamic capacity allocation. Transp. Sci., 39, p. 367-382.

Oum, T.H., Zhang, A., Zhang, Y. (2000). Optimal demand for operating lease of aircraft. Transp. Res. B Methodol., 34, p. 17-29.

Ozdemir, Y., Basligil, H., Karaca, M. (2011). Aircraft Selection Using Analytic Network Process: a Case for Turkish Airlines. http://www.iaeng.org/publication/ WCE2011/WCE2011, 1155-1159.pdf. Erişim Tarihi 03.01.2018.

Pai, V. (2010). On the factors that affect airline flight frequencies and aircraft size. J. Air Transp. Manag., 16, p. 169-177.

Snow, J. (2004). Fleet Planning Workshop June, Cranfield University.

Taylor, J.W.R. (2005). "Jane's All the World Aircraft", Jane's Publishing Company. (2004-2005).

Teodorovic, D. (1999). Fuzzy logic systems for transportation engineering: the state of the art. Transp. Res. A Policy Pract., 33, p. 337-364.

Wei, W., Hansen, M., (2005). Impact of aircraft size and seat availability on airlines' demand and market share in duopoly markets. Transp. Res. E Logist. Transp. Rev., 41, p. 315-327. 